Archives de sciences sociales des religions

114 | avril-juin 2001

Varia

\title{
CHANTIN (Jean-Pierre), Le Jansénisme
}

Paris, Cerf, 2000, 126 p. (coll. « Bref ») (cf. Arch. supra, pp. 21-37)

\section{(2) OpenEdition}

\section{Journals}

Édition électronique

URL : http://journals.openedition.org/assr/20869

DOI : $10.4000 /$ assr.20869

ISSN : $1777-5825$

\section{Éditeur}

Éditions de l'EHESS

Édition imprimée

Date de publication : 1 juin 2001

Pagination : 132

ISBN : 2-222-96704-X

ISSN : 0335-5985

\section{Référence électronique}

«CHANTIN (Jean-Pierre), Le Jansénisme », Archives de sciences sociales des religions [En ligne], 114 I

avril-juin 2001, document 114.65, mis en ligne le 19 août 2009, consulté le 24 septembre 2020. URL

http://journals.openedition.org/assr/20869 ; DOI : https://doi.org/10.4000/assr.20869

Ce document a été généré automatiquement le 24 septembre 2020.

(c) Archives de sciences sociales des religions 


\section{CHANTIN (Jean-Pierre), Le Jansénisme}

Paris, Cerf, 2000, 126 p. (coll. « Bref ») (cf. Arch. supra, pp. 21-37)

\section{RÉFÉRENCE}

CHANTIN (Jean-Pierre), Le Jansénisme, Paris, Cerf, 2000, 126 p. (coll. « Bref ») (cf. Arch. supra, pp. 21-37) 